\title{
ANALISIS FISIKOKIMIA GULA AREN CAIR
}

Oleh :

Yopi Setiawan

Universitas Al - Ghifari, Bandung, Indonesia

\begin{abstract}
Abstrak
Gula cair merupakan cairan berwarna jernih, memiliki rasa manis, kental dan tidak berbau. Gula aren cair atau sirup aren dapat diproleh dari bahan baku nira segar dan gula merah grundulan dengan cara dipanaskan dan diangkat sebelum gula mengkristal. Penelitian ini bertujuan untuk mendapatkan hasil terbaik dari analisa gula cair aren berdasarkan analisis fisikokimia. Metode yang digunakan pada penelitian ini adalah Metode Rancangan Perlakuan, Rancangan Percobaan, Rancangan Respon. Nilai viskositas terbaik dari analisa gula cair aren berdasarkan analisis fisikokimia yang diambil dari berbagai produsen yaitu sampel a2 dengan nilai viskositas $612 \mathrm{cps}$.
\end{abstract}

Kata Kunci: Gula aren, gula aren cair, nira, fisikokimia, viskositas.

\begin{abstract}
Abstrac
Liquid sugar is a clear colored liquid, has a sweet, thick and odorless taste. Liquid palm sugar or palm syrup can be obtained from the raw material of fresh juice and brown sugar by heating and removing it before the sugar crystallizes. This study aims to get the best results from the analysis of palm sugar based on physicochemical analysis. The method used in this study is the Treatment Design Method, Experimental Design, Response Design. The best viscosity value from the analysis of liquid palm sugar based on physicochemical analysis taken from various manufacturers is a2 sample with a viscosity value of 612 cps.
\end{abstract}

Keywords: Palm sugar, liquid palm sugar, roomie, physicochemical, viscosity. 


\section{PENDAHULUAN}

Menurut Lempang, 2012 Tanaman aren adalah salah satu tanaman yang umumnya tumbuh jauh di daerah pedalaman. Jenis tanaman ini tumbuh menyebar secara alami di negara-negara kepulauan bagian tenggara.).

Tanaman aren banyak terdapat dan tersebar hampir di wilayah Nusantara, khususnya di daerah-daerah perbukitan yang lembab dan tumbuh secara individu maupun secara berkelompok (Alam dan Suhartati, 2000).

Produk yang berbahan dasar dari aren begitu banyak di pasarkan setiap harinya dan permintaan produk-produk tersebut untuk kebutuhan dalam negeri maupun untuk ekspor. Hampir semua bagian tanaman aren bermanfaat dan dapat digunakan untuk berbagai kebutuhan, baik bagian fisik (daun, batang, ijuk, akar, dll.) maupun bagian produksinya (buah, nira dan pati/tepung) (Lempang, 2012).

Tanaman aren adalah jenis tumbuhan palma yang memproduksi nira, dalam setahun dapat disadap sampai 4 tandan bunga per pohon, dan setiap tandan bunga dapat disadap 3-5 bulan (Lempang, 2012).

Nira merupakan cairan bening yang diperoleh dari air tandan bunga tanaman dengan cara penyadapan atau penderesan. Nira memiliki rasa manis, berbau harum, dan tidak berwarna. Komposisi nira aren umumnya terdiri dari karbohidrat, protein, lemak, dan air. Komposisi tersebut dipengaruhi oleh umur tanaman, kesehatan tanaman, keadaan tanah, serta iklim (Safitri, 2017).

Nira aren diperoleh dengan penyadapan tangkai bunga jantan Dalam sehari-hari pohon nira dapat disadap 2 kali sehari dengan penghasilan 3-10 liter nira (Reza, 2008).

Kandungan yang dimiliki oleh nira aren segar antara lain total gula 13.9$14.9 \%$, kadar abu $0.4 \%$, kadar protein $0.2 \%$ dan kadar lemak $0.02 \%$. Nira yang baru menetes dari tandan mempunyai $\mathrm{pH}$ sekitar 7 Selain itu, nira juga mengandung asam-asam organik seperti malat, asam askorbat, asam laktat, asam asetat, asam sitrat, asam piroglutamat dan asam fumarat yang berperan dalam pembentukan flavor pada gula merah (Lempang dan Mangopang 2012).

Beberapa jenis produk yang berbahan baku nira yaitu gula, minuman palm wine, nata de pinna, dan bioethanol (Lempang, 2012). Gula aren pada umumnya terdapat dalam tiga bentuk yaitu gula cetak (kerekan), gula pasir dan gula semut, akan tetapi ada juga yang diproduksi dalam bentuk gula cair (Lempang, 2012).

Gula cetak pada umumnya memiliki bentuk sesuai bentuk cetakan yang digunakan. Gula semut merupakan jenis gula yang dibuat dari nira dengan bentuk serbuk atau kristal dan berwarna kuning kecokelatan sampai coklat (Lempang, 2012).

Menurut Rika, 2019 Gula cair adalah cairan berwarna jernih, memiliki rasa manis, kental dan tidak berbau. Dalam gula cair mengandung D-glukosa, maltosa, dan polimer Dglukosa (Rika, 2019).

Gula cair aren atau sirup aren dapat diproleh dari bahan baku nira segar dan gula merah. Gula cair aren dengan bahan baku nira, proses pengolahannya sama dengan proses pembuatan gula merah yaitu nira yang sedang dipanaskan dalam proses pembuatan gula merah diangkat sebelum gula mengkristal, tetapi telah mencapai tahap dimana nira telah mendidih dan berbentuk buih yang meluap-luap berwarna kuning kecoklatan diseluruh permukaan sirup dan buih tersebut semakin lama akan meluap naik (seperti sarang lebah) (Lelya H. 2014).

Gula hasil pengolahan secara konvensional berbentuk padat dan cukup keras yang mengharuskan para konsumen untuk mengiris dan melarutkannya terlebih dahulu sebelum digunakan. Hal ini merupakan sesuatu yang tidak efisien bagi konsumen sekaligus bagi para produsen gula tradisional, maka dari itu perlu dikembangkan produk gula dalam bentuk cair. Adanya produk gula yang dimodifikasi berbentuk gula cair merupakan salah satu alternatif yang nantinya diharapkan dapat memenuhi Standar Nasional Indonesia (SNI) dan 
lebih memudahkan konsumen dari segi penggunaanya. Selain itu bagi para produsen akan lebih efisien dalam proses pengolahan karena waktu yang digunakan lebih singkat dibandingkan ketika gula dibentuk dalam bentuk padatan.

Viskositas menunjukan tingkat kekentalan suatu produk, Semakin tinggi viskositas produk maka semakin kental produk tersebut (Fajri Annur dkk, 2017), penelitian ini bertujuan untuk mendapatakan hasil terbaik sifat fisikokimia (viskositas) dari gula cair aren dengan membandingkan gula cair yang diperoleh dari bahan baku nira segar dan bahan baku gula gula merah.

Maksud dari penelitian ini yaitu mempermudah konsumen dari segi pemakaian gula aren yang memenuhi Standar Nasional Indonesia (SNI) dan bagi produsen dapat menghemat biaya produksi. Tujuan dari penelitian ini untuk mendapatkan hasil terbaik dari analisa gula cair aren berdasarkan analisis fisikokimia.

\section{Kerangka Pemikiran}

Gula palma adalah gula yang dihasilkan dari pengolahan nira pohon palma yaitu Aren (Arenga pinnata Merr), Kelapa (Cocos nucifera Linn) atau jenis palma lainnya dan berbentuk cetak atau serbuk/granula (Imanda, 2007). Gula palma atau sering disebut gula merah atau gula aren umumnya digemari karena memiliki rasa dan aroma yang khas yang tidak terdapat pada gula tebu ataupun pemanis lainnya.

Dalam penggunaannya, selain digunakan dalam bentuk gula merah cetak, gula semut dan gula merah serbuk yang berbentuk padat, gula merah juga banyak digunakan dalam bentuk sirup aren atau sering disebut dengan kinca. Gula merah pada saat digunakan terkadang harus dicairkan terlebih dahulu, misalnya dalam pembuatan es cendol/es dawet, bubur sumsum, mengingat dipasaran gula palma tersedia dalam bentuk gula cetak dan serbuk, adanya produk gula palma yang dimodifikasi berbentuk sirup merupakan terobosan baru yang nantinya diharapkan dapat lebih memudahkan konsumen dari segi kepraktisan penggunaannya.

Produk minuman gula cair aren memiliki potensi yang baik untuk dikembangkan. Hal ini didukung oleh beberapa keistimewaan yang dimiliki oleh sirup aren dibandingkan dengan jenis sirup lain yang ada. Keistimewaan tersebut diantaranya adalah kekhasannya dalam segi rasa dan aroma yang tidak dapat digantikan oleh jenis sirup lain. Selain itu, sirup aren memiliki kelebihan dalam hal nilai gizi dimana gula palma memiliki kandungan protein, kalsium, fosfor, dan zat besi yang jauh lebih tinggi dibandingkan dengan gula tebu/gula pasir.

Menurut Sinko, 2012 Viskositas adalah ketidak leluasaan pengaliran cairan yang disebabkan oleh gaya gesekan dibagian dalam suatu fluida. Penentuan kecepatan aliran suatu zat cair gula cair aren dengan menggunakan viscometer Brookfiled.

Viscometer brookfile merupakan salah satu viscometer yang menggunakan gasing atau kumparan yang dicelupkan ke dalam zat uji dan mengukur tahanan gerak dari bagian yang berputar. prinsip kerja dari viskomoter Brookfiled ini adalah semakin kuat putaran semakin tinggi viskositasnya sehingga hambatannya semakin besar (Nurrachman., dkk. 2015).

Cara menentukan viskositas suatu zat menggunakan alat viscometer Brookfiled yaitu nilai viskositas didapatkan dengan mengukur gaya punter sebuah rooter silinder (spindle) yang dicelupkan ke dalam sampel. Viscometer Brookfiled memungkinakan untuk mengukur viskositas dengan menggunakan teknik dalam viscometry. Alat ukur kekentalan (yang juga dapat disebut viscometers) dapat mengukur viskositas melalui kondisi aliran berbagai bahan sampel yang diuji. Untuk dapat mengukur viskositas sampel dalam viscometer brookfiled, bahan harus diam di dalam wadah sementara poros bergerak sambal direndam dalam cairan (Nurrachman., dkk. 2015).

Berdasarkan hasil penelitian Sukoyo, 2014 tentang Analisis Pengaruh Suhu Pengolahan dan Derajat Brix 
terhadap Karakteristik Fisikokimia dan Sensoris Gula Kelapa Cair dengan Metode Pengolahan Vakum, di dapatkan hasil Rerata viskositas dari gula kelapa cair akibat perbedaan suhu pengolahan vakum dan perbedaan derajat brix berkisar antara 166.67 (Cp) sampai 3713.33 (Cp) (Sukoyo 2014).

Hasil analisa viskositas gula cair dari nira aren menggunakan instrumen Falling Ball Viscometer dengan cara mengukur waktu yang dibutuhkan oleh suatu bola jatuh melalui sampel pada jarak tertentu. Rata-rata nilai viskositas gula cair dari nira aren sebagai kontrol (tanpa penambahan glukosa) yaitu $75^{\circ}$ Brix pada perlakuan kemasan PET 1,80 cp, BG 1,85 cp, SP 1,84 cp. Nilai viskositas gula cair dari nira aren dengan penambahan glukosa $20 \%{ }^{\circ}$ Brix, yaitu: pada kemasan PET 4,23 centipoise; Botol Gelas (BG) 4,4 cp; dan Stand Up Pouch Plastic (SP) 4,35 cp. Dengan penambahan glukosa pada gula cair dari nira aren dapat menghambat kristalisasi (Yunita F dkk., 2018).

Hasil analisis viskositas Penambahan Karagenan Pada Pembuatan Sirup Dari Bonggol Nanas, berbeda nyata pada setiap perlakuan. Nilai rata- rata viskositas sirup berkisar antara 56,48632,42cP (Fajri dkk, 2107). Berdasarkan penelitian yang tekah dilakukan tentang karakteristik fisiko-kimia sirup mangrove pidada dengan penambahan $\mathrm{cmc}$ dan lama pemanasan, Nilai viskositas dengan lama pemanasan 15 menit untuk semua penambahan konsentrasi CMC $\quad(0 \%$ hingga 5\%) lebih tinggi dibandingkan dengan lama pemanasan 5 menit dan 10 menit. Nilai viskositas dengan lama pemanasan 15 menit dan penambahan cmc sebesar $0,5 \%$ adalah $39.564 \mathrm{cP}$ (Deviarni dan Sri Warastuti 2107).

Parameter yang akan di gunakan dalam penelitian ini adalah pengujian viskositas gula cair dari aren dengan membandingkan gula cair yang diperoleh dari bahan baku nira segar dan bahan baku gula gula merah.

\section{Hipotesa Penelitian}

Berdasarkan kerangka pemikiran diatas, dapat diduga bahwa nilai fisikokimia hasil sampel terbaik sesuai dengan syarat mutu produk gula aren cair berdasarkan Standar Nasional Indonesia (SNI).

\section{METODE PENELITIAN}

\section{Waktu dan Tempat Penelitian}

Penelitian ini dilakukan di Laboratorium Teknologi Pangan, Fakultas Teknologi Pertanian, Universitas AlGhifari, Jalan Cisaranten Kulon N0. 140 Bandung 40293.

\section{Bahan Penelitian}

Untuk mendapatkan hasil yang maksimal dari segi kualitas dan kuantitas, bahan dan alat penelitian harus diperhatikan. Adapun bahan dan alat yang digunakan dalam penelitian ini yaitu meliputi bahan produk dan bahan analisis, serta alat analisis. Bahan dan alat untuk menganalisis fisikokimia pada sampel gula aren cair memerlukan bahan penelitian dan alat penelitian sebagai beikut:

\section{Bahan-Bahan yang Digunakan}

Bahan produk yang digunakan dalam penelitian ini yaitu sampel gula cair aren dari nira segar yang berasal dari Kecamatan Sobang, Kabupaten Lebak Provinsi Banten dengan berbagai produsen. Bahan analisis yang digunakan dalam penelitian ini yaitu aquadest

\section{Alat-Alat yang Digunakan}

Alat-alat yang digunakan pada penelitian ini adalah pengaduk atau spatula, gelas kimia, viscometer Brookfield.

\section{Metoda Penelitian}

Metode penelitian yang digunakan meliputi: (1) Rancangan Perlakuan (2) Rancangan Percobaan (3) Rancangan Respon.

\section{Rancangan Perlakuan}

Pada penelitian ini dilakukan analisis viskositas dengan perlakuan gula cair aren dari produsen yang berbeda. Hal ini ditunjukan agar peneliti dapat membandingkan nilai viskositas pada sampel gula aren cair dari produsen gula 
aren cair yang berbeda. Kemungkinan kadar viskositas pada sampel gula cair aren yang berbeda akan mendapatkan hasil yang berbeda pula.

Penentuan pengrajin gula cair aren untuk pengambilan sampel dilakukan di satu lokasi yaitu desa sukaresmi, kecamatan sobang, kabupaten lebak, provinsi banten. Penentuan lokasi ini didasarkan atas perlakuan pengolahan pada setiap pengrajin gula aren. Setiap pengrajin biasanya hanya menganalisa $\mathrm{pH}$ nira segar dengan indera penciuman yang akan mengakibatkan berbeda pada kondisi gula aren padat maupun gula cair aren.

Adapun rancangan perlakuan penelitian sampel gula cair aren yang dilakukan oleh peneliti sebagai berikut:

\begin{tabular}{ccc}
\hline & Sampel \\
\hline Produsen 1 & Produsen 2 & Produsen 3 \\
a1 & a2 & a3 \\
\hline
\end{tabular}

Dimana :

a1: Gula Aren Cair Berbahan Baku Nira Segar Dari Produsen 1

a2: Gula Aren Cair Berbahan Baku Nira Segar Dari Produsen 2

a3: Gula Aren Cair Berbahan Baku Nira Segar Dari Produsen 3

\section{Rancangan Percobaan}

Pada penelitian ini dilakukan percobaan analisis viskositas dengan pengambilan sampel di Desa Sukaresmi,
Kecamatan Sobang, Kabupaten Lebak, Provinsi Banten. Sampel diperoleh dari produsen yang berbeda dengan pengamatan fisikokimia yaitu viskositas.

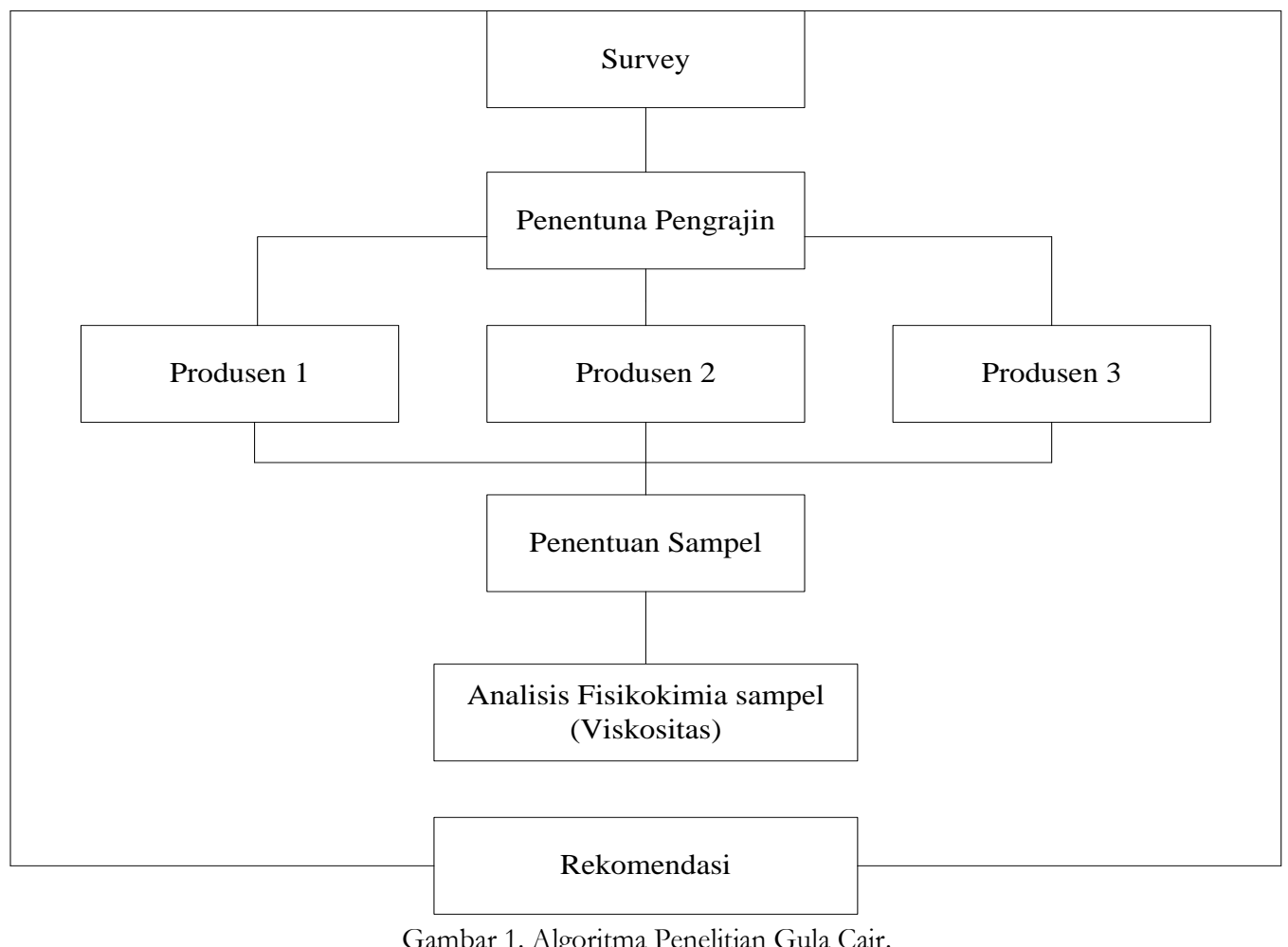

Penentuan pengrajin gula aren merupakan salah satu bagian terpenting pada penelitian ini, hal tersebut dikarenakan pengrajin adalah orang yang menentukan kondisi atau hasil akhir gula cair yang kemudian akan menjadi tempat pengambilan sampel.
Sampel yang digunakan dalam penelitian ini adalah gula cair aren dari nira segar dari berbagai produsen. Penentuan sampel ini didasarkan atas perlakuan bahan yang berbeda, sehingga kemungkinan viskositas (kekentalan) pada ketiga jenis sampel tersebut berbeda. 
Prosedur penelitian untuk penentuan sampel yaitu dengan metode Viskometer Brookfiled. Sampel kemudian dianalisis di laboratorium dengan menggunakan alat Viskometer Brookfield Mode LVT Serial Number 8545051. Parameter yang diamati dalam penelitian ini yaitu analisis viskositas (kekentalan) pada gula aren cair.

\section{Rancangan Respon}

Analisa fisika yang dilakukan adalah pengujian viskositas dengan metode viscometer (brookfield) dengan prinsip memasukan spindle kedalam bahan dan dibaca viskositas larutan sampel pada alat kemudian dilakukan perhitungan sesuai faktor konversi.

\section{Deskripsi Penelitian Utama}

Proses pembuatan produk gula cair melalui beberapa tahapan yaitu sebagai berikut:

\section{Penyaringan Nira dari Kotoran}

Filtrasi (Penyaringan) merupakan proses pemisahan padatan yang terlarut di dalam air (Sujana Alamsyah, 2006). Penyaringan Nira dari Kotoran Seharusnya nira yang diperoleh dari pohon aren segera diperiksa derajat keasamannya $(\mathrm{pH})$. Nira aren dengan $\mathrm{pH}$ 6-7 masih baik untuk diolah menjadi gula aren. Sebelum dimasak, nira perlu disaring terlebih dahulu untuk menghilangkan kotoran. Penyaringan dilakukan dua kali, pertama penyaringan terhadap kotoran kasar seperti ranting, daun dan serangga, serta kedua penyaringan terhadap kotoran halus yang dilakukan pada saat proses pemasakan dimana kotoran terkumpul di permukaan.

\section{Pemasakan}

Pemasakan dilakukan di dalam penggorengan di atas tungku apai dengan bahan bakar kayu. Selama proses pemasakan akan dilakukan penyaringan kotoran halus yang dapat dilakukan dengan menggunakan sreokan.

Sirup aren diperoleh dengan bahan baku nira segar, nira yang sedang dipanaskan dalam proses pembuatan gula merah diangkat sebelum gula mengkristal, tetapi telah mencapai tahap dimana nira telah mendidih dan berbentuk buih yang meluap luap-luap berwarna kuning kecoklatan diseluruh permukaan sirup dan buih tersebut semakin lama akan meluap naik (seperti sarang lebah).

\section{Pengemasan}

Gula aren cair setelah proses pemasakan akan dikemas dalam botol kaca.

\section{HASIL DAN PEMBAHASAN}

\section{Pendahuluan}

Viskositas adalah ukuran yang menyatakan kekentalan suatu cairan atau fluida. Kekentalan merupakan sifat cairan yang berhubungan erat dengan hambatan untuk mengalir sedangkan reologi merupakan aliran dari suatu cairan (Alferd Martiin, 2008). Prinsip dari alat Viscometer Brookfield yaitu rotasi dengan mengkombinasikan setting spindle dan kecepatan putar spindle. Penggunaan spindle harus disesuaikan dengan kekentalan suatu bahan yang akan diuji viskositasnya. Semakin besar nomor spindle maka semakin kecil bentuk fisiknya.

1. Nilasi Viskositas Sampel a1

Hasil viskositas sampel a1 menggunakan Viskometer Brookfield Mode LVT Serial Number 8545051, dengan spindle No.63 dan Speed $30 \mathrm{rpm}$ dapat dilihat pada tabel 1.

Tabel 1. Hasil Nilasi Viskositas Sampel a1.

\begin{tabular}{cccc}
\hline Pengulangan & Dial Reading & Faktor & Nilai Viskositas (Cps) \\
\hline 1 & 68 & 40 & 2720 \\
2 & 68 & 40 & 2720 \\
3 & 67,5 & 40 & 2700 \\
4 & 67,5 & 40 & 2700 \\
5 & 67,5 & 40 & 2700 \\
\hline \multicolumn{4}{c}{ Nilai Rata-Rata Viskositas } \\
\hline
\end{tabular}


2. Hasil Nilasi Viskositas Sampel a2

Hasil viskositas sampel a2 menggunakan Viskometer Brookfield
Mode LVT Serial Number 8545051, dengan spindle No.62 dan Speed $30 \mathrm{rpm}$ dapat dilihat pada tabel 2 .

Tabel 2. Hasil Nilasi Viskositas Sampel a2.

\begin{tabular}{cccc}
\hline Pengulangan & Dial Reading & Faktor & Nilai Viskositas (Cps) \\
\hline 1 & 53 & 10 & 530 \\
2 & 52 & 10 & 520 \\
3 & 53 & 10 & 530 \\
4 & 55 & 10 & 550 \\
5 & 51,5 & 10 & 515 \\
\hline \multicolumn{5}{c}{ Nilai Rata-Rata Viskositas } & Mode LVT Serial Number 8545051, \\
\hline 3. Hasil Nilasi Viskositas Sampel a3 & & dengan spindle No.62 dan Speed 30 rpm \\
Hasil & viskositas sampel a3 & dapat dilihat pada tabel 3. & \\
menggunakan & Viskometer Brookfield & & \\
Tabel 3. Hasil Nilasi Viskositas Sampel a1. & & & \\
\hline Pengulangan & Dial Reading & Faktor & 610 \\
\hline 1 & 61 & 10 & 605 \\
2 & 60,5 & 10 & 610 \\
3 & 61 & 10 & 630 \\
5 & 61,5 & 10 & $\mathbf{6 1 4}$ \\
\hline
\end{tabular}

Sehingga perbedaan tersebut dapat dilihat pada grafik di bawah ini :

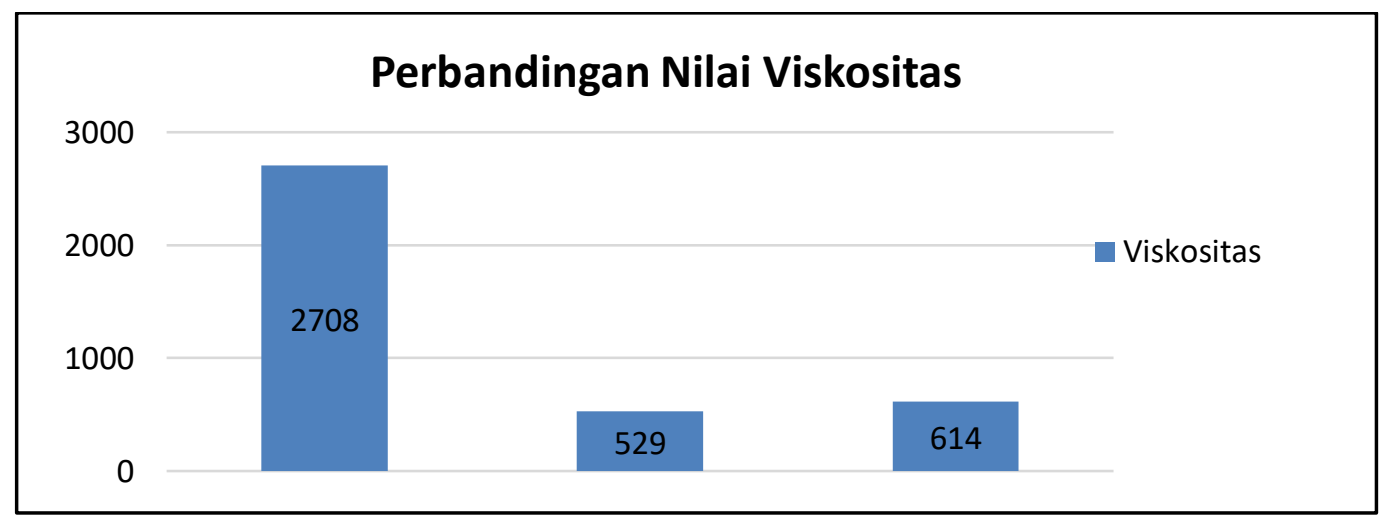

Grafik 1. Grafik Perbandingan Nilai Viskositas.

Berdasarkan hasil penelitian analisis viskositas gula aren cair didapatkan hasil paling tinggi adalah sampel a1 dengan nilai viskositas $2708 \mathrm{cps}$ dan yang paling rendah adalah sampel a2 dengan nilai viskositas 529 cps, hal tersebut dipengaruhi oleh beberapa faktor diantaranya:

Proses produksi gula cair aren umumnya dikerjakan oleh pengrajin skala kecil dan rumah tangga yang dilakukan secara tradisional di pedesaan. Faktor kritis dalam pembuatan gula cair aren adalah kualitas nira dan pemasakan (Muchaymien et al. 2014). Sedangkan faktor penghambat dalam pembuatan gula aren cair antara lain keterbatasan teknologi pengolahan, sarana produksi, dan konsistensi proses pengolahan.

a. Nira merupakan cairan bening yang diperoleh dari air tandan bunga tanaman dengan cara penyadapan atau penderesan (Baharuddin et al. 2007). Nira memiliki rasa manis, berbau harum, dan tidak berwarna. Komposisi nira aren umumnya terdiri dari karbohidrat, protein, lemak, dan air. Komposisi tersebut dipengaruhi oleh umur tanaman, kesehatan tanaman, keadaan tanah, serta iklim (Potoh et al. 2011). Menurut Potoh (2007), kandungan yang dimiliki oleh nira aren segar antara lain total gula $13.9-14.9 \%$, kadar abu $0.4 \%$, kadar protein $0.2 \%$ 
dan kadar lemak $0.02 \%$. Nira yang baru menetes dari tandan mempunyai $\mathrm{pH}$ sekitar 7 (Lempang dan Mangopang 2012). Selain itu, nira juga mengandung asam-asam organik seperti malat, asam askorbat, asam laktat, asam asetat, asam sitrat, asam piroglutamat dan asam fumarat yang berperan dalam pembentukan flavor pada gula merah (Limo et al. 2015).

Nira sangat rentan akibat kerusakan enzimatis dan mikrobiologis karena kandungan gula yang tinggi. Nira yang telah mengalami fermentasi dengan kadar etanol 4\% dikenal dengan tuak. Jika proses fermentasi tersebut dibiarkan berlangsung terus, fermentasi akan berlanjut sehingga akan terbentuk asam cuka (Baharuddin et al. 2008). Kondisi tersebut tidak dapat digunakan sebagai bahan baku pembuatan gula cair aren sesuai dengan standar.

b. Pemasakan gula cair aren merupakan salah satu proses pengolahan pangan yang menggunakan prinsip evaporasi. Evaporasi merupakan proses pemasakan dimana air diuapkan dari bahan pangan yang bersifat cair dengan tujuan untuk mengentalkan, meningkatkan total padatan, mengurangi aktivitas air, dan meningkatkan perubahan warna atau flavor (Estiasih dan Ahmadi 2011). Semakin lama waktu pemasakan maka kadar air dalam bahan akan semakin menurun dan nilai viskositas semakin tinggi (Tabel 1 dan 2).

Tabel 4. Satndar Mutu Sirup Glukaosa diatur berdasarkan SNI 01-2978-1992.

\begin{tabular}{ll}
\hline \multicolumn{1}{c}{ Keadaaan } & \multicolumn{1}{c}{ Standar Mutu Glukosa } \\
\hline Bau & Tidak Berbau \\
Rasa & Manis \\
Warna & Tidak berwarna \\
Air $(\% \mathrm{~b} / \mathrm{b})$ & Maks 20 \\
Abu $(\%)$ & Maks 1 \\
Gula Pereduksi $(\% \mathrm{~b} / \mathrm{b})$ & Min 30 \\
Pati & Tidak nyata \\
Cemaran Logam & \\
$\quad$ - Timbal $(\mathrm{Pb}) \mathrm{mg} / \mathrm{kg}$ & Maks 1,0 \\
$\quad$ - Tembaga $(\mathrm{Cu}) \mathrm{mg} / \mathrm{kg}$ & Maks 10,0 \\
$\quad$ - Seng $(\mathrm{Zn}) \mathrm{mg} / \mathrm{kg}$ & Maks 25,0 \\
$\quad$ - As), $\mathrm{mg} / \mathrm{kg}$ & Maks 0,5 \\
Cemaran Mikroba & \\
$\quad$ Total Plate Count & Maks $5 \times 10^{2} \mathrm{koloni} / \mathrm{g}$ \\
$\quad$ Kapang & Maks $50 \mathrm{koloni} / \mathrm{g}$ \\
\hline
\end{tabular}

Sumber: SNI 01-2978-1992.

Proses pemasakan akan menyebabkan terjadinya reaksi non-enzimatis karamelisasi dan maillard yang memberikan warna coklat kemerahan pada produk pangan. Reaksi karamelisasi merupakan reaksi yang terjadi karena pemakaian suhu tinggi pada sukrosa atau gula (Winarno 1992), pemasakan dapat berlangsung dalam kondisi asam, basa dan pemasakan tanpa air (Sutrisno dan Susanto 2014). Reaksi maillard adalah reaksi yang terjadi antara asam amino dengan gula pereduksi apabila dipanaskan bersama-sama menghasilkan senyawa melanoidin (Sukoyo et al. 2014). Warna cokelat yang dihasilkan dari reaksi karamelisasi dan maillard memiliki jenis yang berbeda berdasarkan jenis gula, jenis asam amino, suhu dan lama pemasanan (Kroh 1994).

Berdasarkan Standar Nasional Indonesia (SNI) 01-2978-1992, bahwa kadar air sirup glukosa maks 20\%. Dan berdasarkan hasil penelitian semakin tinggi nilai derajat brix akan menyebabkan kenaikan viskositas (Agung Sukoyo dkk, 2014). Semakin lama waktu penguapan akan dapat menyebabkan kenaikan viskositas. Hal ini disebabkan karena air yang menguap akan semakin banyak dan total padatan terlarut semakin meningkat, sehingga viskositas akan meningkat (Diniyah dkk., 2012). Sehingga dapat disimpulkan bahwa nilai viskositas terbaik dari analisa gula cair aren berdasarkan analisis fisikokimia yang diambil dari berbagai produsen yaitu sampel a2 dengan nilai viskositas $612 \mathrm{cps}$. 


\section{KESIMPULAN}

Setelah melakukan analisis fisikokimia pada gula cair aren berdasarkan Standar Nasional Indonesia (SNI) yang diperoleh dari berbagai produsen dapat disimpulkan bahwa menurut Standar Nasional Indonesia (SNI) 01-2978-1992, bahwa kadar air sirup glukosa maks 20\%. Dan berdasarkan hasil penelitian semakin tinggi nilai derajat brix akan menyebabkan kenaikan viskositas (Agung Sukoyo dkk, 2014). Semakin lama waktu penguapan akan dapat menyebabkan kenaikan viskositas. Hal ini disebabkan karena air yang menguap akan semakin banyak dan total padatan terlarut semakin meningkat, sehingga viskositas akan meningkat (Diniyah dkk., 2012). Sehingga dapat disimpulkan bahwa nilai viskositas terbaik dari analisa gula cair aren berdasarkan analisis fisikokimia yang diambil dari berbagai produsen yaitu sampel a2 dengan nilai viskositas $612 \mathrm{cps}$.

\section{DAFTAR PUSTAKA}

Agung S., Bambang Dwi Argo, Rini Yulianingsih. 2104. Jurnal Bioproses Komoditas Tropis Vol. 2 No.2. Malang.

Alam, S. dan Suhartati, 2000. Pengusahaan hutan aren rakyat di Desa Umpunge Kecamatan Lalabata Kabupaten Soppeng Sulawesi Selatan. Buletin Penelitian Kehutanan Vol.6 No.2 2000 : 5970. Balai Penelitian Kehutanan, Ujung Pandang.

Anonim. 2012. Penuntun Praktikum Mikrobiologi. Laboratorium Biologi UMS: Surakarta.

Atknis, P. 2007. Chemical Principles: Quest for Insight $4^{\text {th }}$ Edition. New York: W.H.Freeman and Company.

Bourne MC. 2002. Food Texture and Viscosity: Concept and Measurement 2nd edition. London (UK): Elsevier Science \& Technology Books.

Badan Standardisasi Nasional [BSN]. 1995. Gula Palma. SNI 01-37431995.
BTPN-Banten. 2005. Kajian Sosial Ekonomi Aren di Banten. Balai Pengkajian Teknologi Pertanian Banten.

Deviarni dan Sri Warastuti. 2107. Karakteristik Fisiko-Kimia Sirup Mangrove Pidada Dengan Penambahan Cmc Dan Lama Pemanasan. Jurnal Galung Tropika, 6 (3) Desember 2017, hlmn. 213 223. Pontianak

Diniyah, N., Wijanarko, S. B. \& Purnomo, H. 2012. Teknologi Pengolahan Gula Coklat Cair Nira Siwalan. (Borassus flabellifer L.). Jurnal Teknologi dan Industri PanganVolXXIII No 1. Tahun 2012.

Effendi. 2010. Prospek Pengembangan Tanaman Aren (Arenga pinnata Merr) Mendukung Kebutuhan Bioetanol di Indonesia. Bogor.

Effendi, 2010. Kimia Pangan Dan Gizi. PT. Gramedia. Jakarta

Fajri dkk. 2017. Penambahan Karagenan pada Pembuatan Sirup dari Bonggol Nanas. https://jom.unri.ac.id/index.php/I OMFAPERTA/article/view/1705

2. Diakses pada bulan November 2017.

Firlieyanti, A.S, 2003. Kajian Pembuatan Dan Sifat-Sifat Sirup Gula Palma. Skripsi. Jurusan Teknologi Pangan Dan Gizi, Fakultas Teknologi Pertanian IPB. Bogor.

Kristianingrum. 2009. Analisis Nutrisi Dalam Gula Semut. Jurusan Pendidikan Kimia Fakultas Matematika dan Ilmu Pengetahuan Alam Universitas Negri Yogyakarta. Yogyakarta

Lempang. 2012. Pohon Aren Dan Manfaat Produksinya. Balai Penelitian Kehutanan. Makassar.

Lempang M, Mangopang AD. 2012. Efektivitas nira aren sebagai bahan pengembang adonan roti. Jurnal Penelitian Kebutanan Wallacea.

Lelya H. 2104. Jurnal Analisa Tanggapan Responden Terhadap Sirup Aren Yang Dihasilkan Dari Nira Dan Gula Aren. Padang.

Muchaymien Y, Rangga A, Nuraini F. 
2014. Penyusunan draft standard operating procedure (SOP) pembuatan gula merah kelapa (studi kasus di pengrajin gula merah kelapa Desa Purworejo Kec. Negeri Katon Kab. Pesawaran. Jurnal Teknologi Industri dan Hasil Pertanian. Pesawaran.

Nurrachman., dkk. 2015. Laporan Praktikum Farmasi fisika. https://www.academia.edu/23021 505/LAPORAN PRAKTIKUM FARMASI FISIKA Viskositas O stwald. Diakses pada 23 februari 2015

Permentan RI. 2013. Lampiran PEDOMAN BUDIDAYA AREN (Arenga pinnata Merr) YANG BAIK. No 133/Permentan/OT.140/12/2013. Diakses pada tahun 2104.

Rahmawati. 2103. Pengemasan dan pelabelan.http://staff.uny.ac.id/site $\mathrm{s} /$ default/files/pengabdian/fitrirahmawati-mp/pengemasan-dan pelabelan.pdf

Reza. 2008. Ilmu Pengetahuan Bahan Pangan dan Gizi. Institut Pertanian Bogor. Bogor

Rika. 2109. Jurnal Korelasi Waktu
Fermentasi Terhadap Karakteristik Gula Cair Dari Pati Ubi Jalar Yang Difermentasi Dengan Bakteri Bacillus Subtilis. Bandung.

Rindengan, B dan E.Manaroinsong. 2009. Aren. Tanaman Perkebunan Penghasil Bahan Bakar Nabati (BBM). Pusat penelitian dan Pengembangan Perkebunan. hlm.122.

Rumokoi MMM. 1990. Manfaat tanaman aren (Arenga pinnata Merr). Buletin Balitka No. 10 Thn 1990 hal : 2128. Balai Penelitian Kelapa, Manado.

Sinko, P. 2012. Farmasi Fisika dan Ilmu Farmasetika. Jakarta. EGC

Sukoyo. 2104. Analisis Pengaruh Suhu Pengolahan dan Derajat Brix terhadap Karakteristik Fisikokimia dan Sensoris Gula Kelapa Cair dengan Metode Pengolahan Vakum. Jurnal Agro Industri Perkebunan.Malang. Diakses pada 2 november 2019.

Yunita F dkk., 2108. Pengaruh Lama Penyimpanan Terhadap Mutu Gula Cair Dari Nira Aren. Jurnal Penelitian Teknologi Industri.Manado. 